\title{
T-cells contribute to hypertension but not to renal injury in mice with subtotal nephrectomy
}

\author{
Nynke R. Oosterhuis, Diana A. Papazova, Hendrik Gremmels, Jaap A. Joles and Marianne C. Verhaar*
}

\begin{abstract}
Background: The pathological condition of chronic kidney disease may not be adequately recapitulated in immunocompromised mice due to the lack of T-cells, which are important for the development of hypertension and renal injury. We studied the role of the immune system in relation to salt-sensitive hypertension and renal injury in mice with subtotal nephrectomy (SNX).

Methods: Wild-type immunocompetent (WT) and Foxn $1^{\text {nu/nu }}$ athymic immunodeficient (AT) CD-1 mice underwent SNX to induce renal injury after which they received standard chow or a high salt diet (HSD). Four weeks after SNX blood pressure and kidney function parameters were measured.

Results: HSD increased albumin excretion independent of immune status. Systolic blood pressure increased only in WT mice on HSD, not in AT mice. Uremia and morphological damage after SNX were not affected by either HSD or immune status.

Conclusions: For the development of hypertension after SNX in CD-1 mice mature T-cells and a high salt diet are required. SNX induced albuminuria was independent of the presence of T-cells.
\end{abstract}

Keywords: Albuminuria, High salt diet, Hypertension, Subtotal nephrectomy, T-cells

\section{Background}

Cell-based therapy is a promising treatment approach for many degenerative pathological conditions and has been proposed as potential therapeutic strategy in chronic kidney disease [1]. Immunocompromised mice, lacking an adaptive immune system, are often used in pre-clinical studies to test the therapeutic effects of human stem cells [2]. However, the adaptive immune system is also involved in the development and maintenance of hypertension and renal injury [3]. Immunocompromised animals may therefore not adequately resemble the pathological condition of chronic kidney disease (CKD).

In rats with CKD induced by subtotal nephrectomy (SNX), elimination of T-cells by thymectomy or splenectomy prevented the development of hypertension, while transfer of lymph node cells into SNX rats

\footnotetext{
* Correspondence: m.c.verhaar@umcutrecht.nl

Nephrology \& Hypertension, University Medical Center Utrecht, PO Box 85500, 3508GA Utrecht, Netherlands
}

(c) The Author(s). 2017 Open Access This article is distributed under the terms of the Creative Commons Attribution 4.0 International License (http://creativecommons.org/licenses/by/4.0/), which permits unrestricted use, distribution, and reproduction in any medium, provided you give appropriate credit to the original author(s) and the source, provide a link to the Creative Commons license, and indicate if changes were made. The Creative Commons Public Domain Dedication waiver (http://creativecommons.org/publicdomain/zero/1.0/) applies to the data made available in this article, unless otherwise stated. sion in SCID (severe combined immunodeficiency) mice resulted in lower SBP, albumin excretion and renal damage than in wild-type mice [5] and hypertension was not maintained after subtotal nephrectomy in athymic mice [6]. Moreover, immunosuppressive drugs reduce salt-sensitive hypertension and renal inflammation caused by protein overload [7] or ischemia/reperfusion injury [8].

The 5/6th nephrectomy ablation model is a wellknown experimental model of progressive renal disease that resembles many aspects of human CKD, including hypertension, and would be valuable for the study of cell-based therapeutic strategies in CKD and hypertension. However, the development of hypertension and renal injury induced by SNX in combination with a high salt diet has not been explored in immunodeficient athymic Foxn1 mice, a strain commonly used in xenogeneic transplantation. We studied the role of the immune system in 
relation to salt-sensitive hypertension in SNX mice, hypothesizing that T-cells and a high salt diet are required for the development of both hypertension and albuminuria.

\section{Methods}

\section{Animals}

Male wild-type (WT) immunocompetent CD-1 (own breeding colony) and athymic (AT) immunodeficient CD-1 Nude mice (Crl:CD1-Foxn1 ${ }^{\text {nu }}$ ) from Charles River, 9-11 weeks of age were group housed in a light-, temperature- and humidity-controlled environment under standard conditions i.e. a $12 \mathrm{~h}$ light-dark cycle and with free access to water and standard chow. Protocols were approved by the Animal Ethics Committee of Utrecht University. Animal experiments were performed according to ARRIVE guidelines.

\section{Flow cytometry}

T- and B-cells in the blood of WT and AT mice were counted using flow cytometry (Additional file 1) and confirmed the lack of T-cells and presence of B-cells in AT mice (Additional file 1: Figure S1).

\section{Experimental setup}

Subtotal nephrectomy (SNX) was performed as previously described [9]. Via a retroperitoneal incision, the right kidney was excised and weighed. One week later approximately $2 / 3$ of the remaining left kidney was removed. WT and AT mice either received standard diet or high salt diet (HSD, ground chow supplemented with 4-6\% $\mathrm{NaCl}$ (CRM (E) FG; Special Diet Services Ltd., Witham, Essex, UK)), which was started one week after SNX (WT $n=7$, WT + HSD $n=8$, AT $n=16$, AT + HSD $n=10)$. Four weeks after SNX, systolic blood pressure (SBP) was measured by tail-cuff sphygmomanometry; 16-h urine samples were collected by placing mice individually in metabolism cages, and blood was sampled from the cheek plexus.

\section{Biochemical analysis}

Urine albumin was measured with a mouse albumin ELISA (Bethyl Laboratories Inc. Montgomery, TX). Sodium and potassium excretion were determined by flame photometry. Plasma urea was measured by DiaSys Urea CT FS (DiaSys Diagnostic Systems, Holzheim, Germany).

\section{Renal morphology}

Three $\mu \mathrm{m}$ sections were sliced of formaldehyde-fixed, paraffin-embedded kidneys. A periodic acid-Schiff (PAS) staining was performed to visualize renal morphology, including infiltrating cells, tubular fibrosis, glomerular matrix expansion and glomerulosclerosis.

\section{Statistical analysis}

Data are presented as mean \pm standard error (SEM). Flow cytometry data of WT and AT mice were compared using a t-test. A two-way ANOVA, two-way RM ANOVA with Student-Newman-Keuls (SNK) as posthoc test or linear regression were performed where appropriate using SigmaPlot 12.3 (Systat Software Inc., San Jose, CA) to compare groups and determine effects of the immune status and diet. A non-parametric KruskalWallis test was performed on renal fibrosis data. $P<0.05$ was considered significant.

\section{Results}

\section{Baseline characteristics}

At the start of the study, baseline measurement for body weight and SBP were performed on standard chow. Body weight of WT mice was significantly higher compared to AT mice $(36.4 \pm 0.7$ vs. $26.7 \pm 0.6 \mathrm{~g}, p<0.001)$ while SBP of both groups was comparable $(96.7 \pm 3.9$ vs. $96.2 \pm$ $4.0 \mathrm{mmHg}, p>0.05)$.

\section{HSD increased SBP and albuminuria}

HSD versus normal salt intake did not affect body weight of WT mice at week 2 and 4 after SNX (WT $37.6 \pm 1.4$ and $37.9 \pm 1.7 \mathrm{~g}$ vs. WT + HSD $35.6 \pm 0.9$ and $37.0 \pm 1.2 \mathrm{~g}, \mathrm{NS})$, but decreased body weight of AT mice (AT $29.6 \pm 0.5$ and $31.2 \pm 0.5$ g vs. AT + HSD $27.8 \pm 0.5$ and $27.4 \pm 0.8 \mathrm{~g}, p<0.05$ ). Food intake for all groups was comparable at week 2 and 4 as assessed by potassium excretion (K excretion week 4, WT: $523 \pm 66$, WT + HSD: $618 \pm 59$, AT: $637 \pm 38$, AT + HSD: $560 \pm 56 \mu \mathrm{mol} /$ $16 \mathrm{~h}, p>0.05)$. The intake of salt was confirmed by a five-fold increase in sodium excretion in HSD groups (Na excretion week 4, WT: $354 \pm 57$, WT + HSD: $2951 \pm$ 456, AT: $466 \pm 40$, AT + HSD: $2274 \pm 270 \mu \mathrm{mol} / 16 \mathrm{~h}, p<$ $0.001)$. Independent of immune status HSD increased albumin excretion $(p<0.01$; Fig. 1a). On a normal salt intake immune status did not affect SBP (WT: $139 \pm 8$ vs. AT: $127 \pm 6 \mathrm{mmHg}, p>0.1)$. HSD increased SBP in WT mice $(p<0.01)$, but not in AT mice (AT: $127 \pm 6$ vs. AT + HSD: $145 \pm 6 \mathrm{mmHg}, p=0.172$; Fig. 1b). Consequently, SBP was higher in WT + HSD mice compared to AT + HSD mice $(177 \pm 10$ vs. $145 \pm 6 \mathrm{mmHg}, p<0.01)$. Immune status significantly influenced the relationship between SBP and albuminuria $(p<0.01)$, resulting in a positive correlation for SBP vs. albuminuria in AT mice $(R=0.677, p<0.05)$, but not in WT mice $(R=0.410, p>$ 0.05 ; Fig. 1c). HSD did not induce significant differences in urea levels in either WT or AT mice $(18.0 \pm 2.2 \mathrm{vs}$. $24.3 \pm 1.3 \mathrm{mmol} / \mathrm{L}$ and $22.1 \pm 2.6$ vs. $20.2 \pm 0.9 \mathrm{mmol} / \mathrm{L}$ ).

\section{Renal morphology}

PAS-staining was performed to identify renal morphological damage. In all four groups patches of severe 

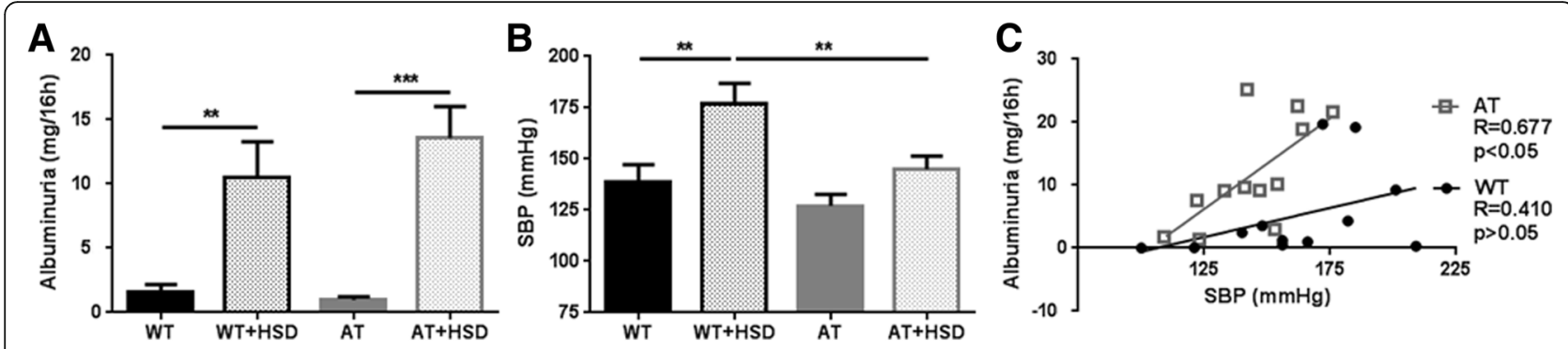

Fig. 1 Albuminuria a, systolic blood pressure (SBP; b) and albuminuria vs. SBP $\mathbf{c}$ at four weeks after subtotal nephrectomy (SNX). WT: wild-type, AT: athymic, HSD: high salt diet. Mean \pm SEM ${ }^{*} p<0.05,{ }^{* *} p<0.01,{ }^{* * *} p<0.001$

tubular inflammation and fibrosis were observed (Fig. 2a). Within those inflamed and fibrotic patches glomerular matrix expansion and glomerulosclerosis were also present. Severely damaged patches were alternated by normal to mildly injured renal tissue. Overall, the degree of tubulo-interstitial fibrosis was comparable between all groups (NS, Fig. 2b).

\section{Discussion}

In the present study, WT SNX mice developed more pronounced hypertension in response to salt loading, compared to AT mice. However, both groups developed albuminuria to a more or less similar level. In this model tubulo-interstitial fibrosis was not related to the presence or absence of T-cells. Neither albuminuria and blood pressure were predictors for renal fibrosis.

The adaptive immune system, particularly T-lymphocytes, has been shown to play a major role in the development and maintenance of hypertension [3] and the response to salt load in various models of renal injury $[4,6,8,10]$. Due to the pervasive effects of gene knock-outs in mouse models on various parts of the adaptive immune system, it is at
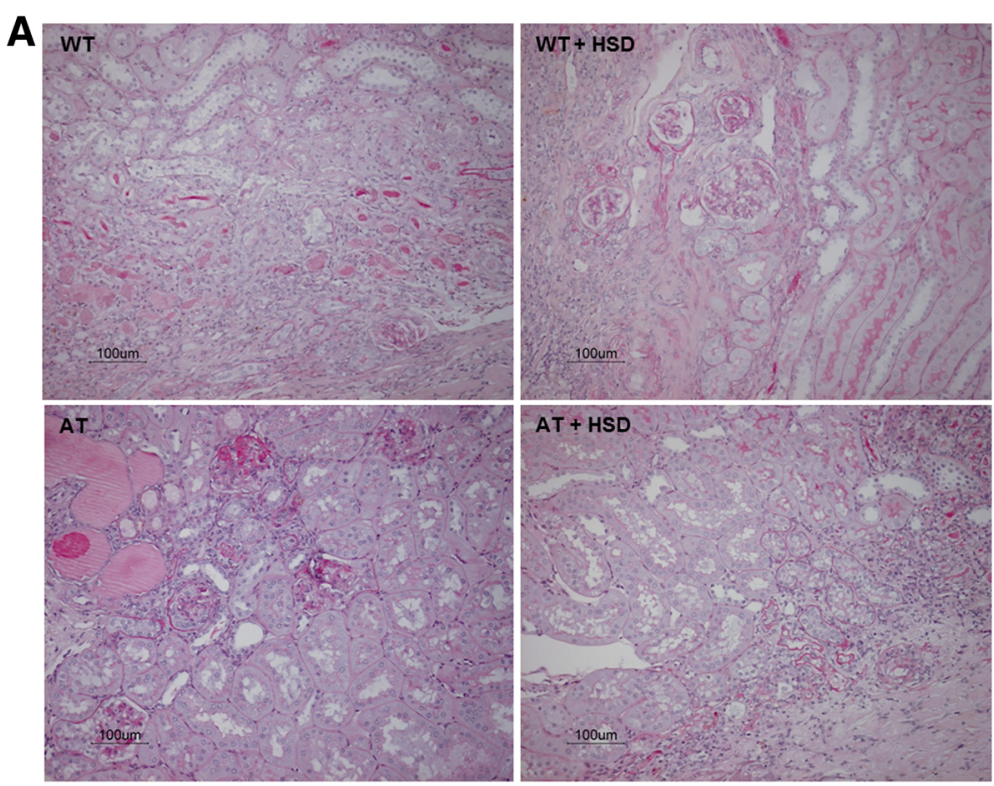

B

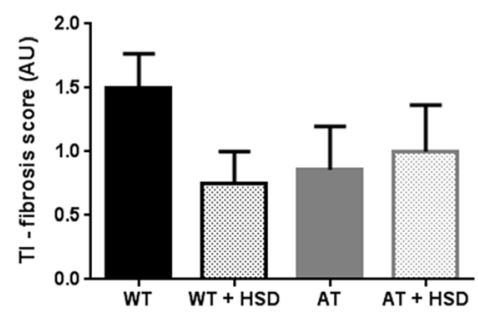

Fig. 2 Representative photomicrographs of periodic acid-Schiff stained renal sections showing patches of severe inflammation and fibrosis in wild-type (WT) and athymic (AT) mice fed with standard diet or high salt diet (HSD) $\mathbf{a}$ and tubulo-interstitial fibrosis scores $\mathbf{b}$ 
present unclear which cell-type is the primary mediator of salt-mediated hypertension. The $\mathrm{CD} 1-\mathrm{FoxN} 1^{\mathrm{nu} / \mathrm{nu}}$ mice employed in this study lack T-cells due a defect in the Foxn1 gene, which controls differentiation of the epithelial thymic meshwork [11]. The immunocompromised phenotype, therefore, arises due to a defect in the thymic niche, rather than an intrinsic defect in lymphocyte maturation. This is in contrast to $\mathrm{Rag}^{-/-}$(Recombination-Activating Gene) immunodeficient mice, in which there is restricted B- and T-cell differentiation due to a defect in VDJ recombination [12].

The differences in hypertension between WT and AT mice observed in this study are likely primarily mediated by a deficient interaction between B- and T-cells. In a previous report, it has been shown that $\mathrm{Rag}^{-/-}$mice, lacking both Tand B-cells, did not develop hypertension after AngII or DOCA (deoxycorticosterone acetate) salt. Transplantation of T-cells into these mice induced hypertension, whereas Bcells did not [13]. Conversely, in B-cell-activating factor receptor-deficient $\left(\mathrm{BAFF}-\mathrm{R}^{-/}\right.$) mice, B-cells fail to mature, but the mice have normal numbers of T-cells. In these animals too, AngII induced hypertension was blunted compared to wild-type mice [14]. Transplantation of B-cells restored the development of hypertension. In the present study we show that FoxN1 ${ }^{\text {nu/nu }}$ mice fail to develop saltmediated hypertension, with a relatively isolated defect in Tcell maturation, but normal numbers of circulating B-cells. We, therefore, propose that T-cell dependent B-cell activation [15], may be important for the development of saltmediated hypertension.

Our data suggest that AT mice are more sensitive to develop albuminuria on a HSD, as a lower SBP associated with a similar increase in albumin excretion as observed in WT mice on a HSD. This is consistent with previous observations that rats on a HSD with acute ischemia/reperfusion injury and treated with immunosuppressive drugs develop albuminuria, even though the immunosuppressive drugs completely blunt the development of salt-induced hypertension [8]. In contrast, in salt-sensitive Dahl rats treated with tacrolimus arterial pressure and albuminuria decrease in parallel [16], even though the number of T-cells was not even reduced by $50 \%$. This suggests that in immunocompromised mice albumin leakage is not induced by systemic hypertension, but by increased permeability of the glomerular filtration membrane or an increase in glomerular hydrostatic pressure. Unfortunately, we were not able to study this in further detail due to lack of the required setup to perform sieving curves and micropuncture respectively. This could be noted as a limitation of our study.

\section{Conclusion}

In conclusion, for the development of hypertension after SNX mature T-cells and a high salt diet are required. SNX induced albuminuria was independent of the presence of T-cells.

\section{Additional file}

Additional file 1: Figure S1. Flow cytometry gating of T- and B-cells (A). T-cell (CD3, CD4 and CD8) and B-cell (CD19) markers in wild-type (WT) and athymic (AT) mice (B). (DOCX $379 \mathrm{~kb})$

\section{Abbreviations}

Angll: Angiotensin-II; AT: Athymic; CKD: Chronic kidney disease; HSD: High salt diet; SBP: Systolic blood pressure; SNX: Subtotal nephrectomy; WT: Wildtype

\section{Acknowledgements}

We thank Petra de Bree, Adele Dijk, Paula Martens, Krista den Ouden, Martijn van Nieuwburg and Danny Elbersen for their excellent technical assistance.

\section{Funding}

MCV is supported by the Netherlands organization for Scientific Research (NWO) VIDI grant (grant number 016.096.359).

\section{Availability of data and materials}

Presented data are part of a larger study with the tendency to be expanded and published in the future. Therefore supporting data is available for review upon request.

\section{Authors' contributions}

NRO, DAP, JAJ and MCV designed the study. NRO, DAP and HG collected and analysed the data. NRO, HG, JAJ and MCV drafted or revised the manuscript. All authors read and approved the final manuscript.

\section{Competing interests}

The authors declare that they have no competing interests.

Consent for publication

Not applicable

Ethics approval and consent to participate Not applicable

\section{Publisher's Note}

Springer Nature remains neutral with regard to jurisdictional claims in published maps and institutional affiliations.

Received: 13 January 2016 Accepted: 13 April 2017

Published online: 08 May 2017

\section{References}

1. Papazova DA, Oosterhuis NR, Gremmels H, Van Koppen A, Joles JA, Verhaar MC. Cell-based therapies for experimental chronic kidney disease: A systematic review and meta-analysis. Dis Models Mech. 2015;8(3):281-93.

2. Li J, Ezzelarab MB, Cooper DKC. Do mesenchymal stem cells function across species barriers? Relevance for xenotransplantation. Xenotransplantation. 2012;19(5):273-85

3. Trott DW, Harrison DG. The immune system in hypertension. Am J PhysiolAdvanc Physiol Educ. 2014;38(1):20-4.

4. Okuda T, Grollman A. Passive transfer of autoimmune induced hypertension in the rat by lymph node cells. Tex Rep Biol Med. 1967;25(2):257-64.

5. Crowley SD, Song YS, Lin EE, Griffiths R, Kim HS, Ruiz P. Lymphocyte responses exacerbate angiotensin II-dependent hypertension. Am J Physiol Regul Integr Comp Physiol. 2010;298(4):R1089-97.

6. Svendsen UG. The role of thymus for the development and prognosis of hypertension and hypertensive vascular disease in mice following renal infarction. Acta Pathologica et Microbiologica Scandinavica - Section A Pathology. 1976;84(3):235-43

7. Alvarez V, Quiroz Y, Nava M, Pons H, Rodríguez-lturbe B. Overload proteinuria is followed by salt-sensitive hypertension caused by renal infiltration of immune cells. Am J Physiol Ren Physiol. 2002;283(5):F1132-41.

8. Pechman KR, Basile DP, Lund H, Mattson DL. Immune suppression blocks sodium-sensitive hypertension following recovery from ischemic acute renal failure. Am J Physiol Regul Integr Comp Physiol. 2008;294(4):R1234-9. 
9. van Koppen A, Verhaar MC, Bongartz LG, Joles JA: 5/6th nephrectomy in combination with high salt diet and nitric oxide synthase inhibition to induce chronic kidney disease in the Lewis rat. J Vis Exp. 2013;(77):e50398.

10. White $\mathrm{FN}$, Grollman A. Autoimmune factors associated with infarction of the kidney. Nephron. 1964;204:93-102.

11. Zhang Z, Burnley P, Coder B, Su DM. Insights on Foxn1 biological significance and usages of the "nude" mouse in studies of T-Lymphopoiesis. Int J Biol Sci. 2012;8(24):1156-67.

12. Mombaerts $\mathrm{P}$, lacomini J, Johnson RS, Herrup K, Tonegawa S, Papaioannou VE. RAG-1-deficient mice have no mature B and T lymphocytes. Cell. 1992; 68(5):869-77.

13. Guzik TJ, Hoch NE, Brown KA, McCann LA, Rahman A, Dikalov S, Goronzy J, Weyand C, Harrison DG. Role of the T cell in the genesis of angiotensin Il-induced hypertension and vascular dysfunction. J Exp Med. 2007;204(10):2449-60.

14. Chan CT, Sobey CG, Lieu M, Ferens D, Kett MM, Diep H, Kim HA, Krishnan SM, Lewis CV, Salimova E, et al. Obligatory role for B cells in the development of angiotensin II-dependent hypertension. Hypertension. 2015;66(5):1023-33.

15. Milićević NM, Nohroudi K, Milićević Z, Hedrich HJ, Westermann J. T cells are required for the peripheral phase of B-cell maturation. Immunology. 2005;11:308-17.

16. De Miguel C, Guo C, Lund H, Feng D, Mattson DL. Infiltrating T lymphocytes in the kidney increase oxidative stress and participate in the development of hypertension and renal disease. Am J Physiol Ren Physiol. 2011;300(3): F734-42.

\section{Submit your next manuscript to BioMed Central and we will help you at every step:}

- We accept pre-submission inquiries

- Our selector tool helps you to find the most relevant journal

- We provide round the clock customer support

- Convenient online submission

- Thorough peer review

- Inclusion in PubMed and all major indexing services

- Maximum visibility for your research

Submit your manuscript at www.biomedcentral.com/submit 